\title{
Ульяновской Областень Новомалыклинской Райононь Эрзянь Велень Кортавкстнэсэ Азорксчинь Невтиця Суффикстнэнь Башка Ёнксост
}

\author{
Нина А. Агафонова, Иван Н. Рябов \\ Саранск \\ ohanina@rambler.ru
}

\begin{abstract}
Аннотация. Статьясонть тевс нолдавить материалтнэ, конат пурназь лингвистической экспедициянь шкасто Ульяновской областень Новомалыклинской райононь эрзянь велень кортавктнэстэ. Эрзянь литературной келенть марто карадо-каршо аравтомась невтизе, неть кортавкстнэсэ ванстовсь седе пешксе кезэрень азорксчинь суффиксэнь системась. Неть кортавкстнэнь касомаст-кепетемаст мольсь башка лия эрзянь кортавкстнэнь эйстэ. Те лездась неень шкас ванстомс азорксчинь суффиксэнь системасонть весе ниле сериятнень, косо апак полавто кадовсть обладательтнень ды обладаемойтнень ютксо ламочинь явовоматне. Истя II сериянь «тонь» куросонть ванстовсь кезэрень азорксчинь суффиксэсь *-nt/*-ńt. III сериянь «минек» куросо тевс нолдави васенце лицянь кезэрень *-mok/*-mek суффиксэсь, кона карадо-каршо аравтови IV сериянь *-nok/*-ńek суффиксэнть марто.
\end{abstract}

Прявт валт: эрзянь кель, диалект, кортавкст, литературной кель, азорксчинь суффикст, обладаемой, обладатель.

1. Ульяновской областень Новомалыклинской районось ашти пек маласо Татарстанонть эйстэ. Истя жо сон ашти шабрасо Ульяновской областень Мелекесской райононть ды Самарской областень Кошкинской райононть марто. Районсонть неень шкас ванстовсть истямо эрзянь велеть: Новая Малыкла (Од Малыкла), Высокий Колок (Тимошкань Тошк или Колка), Старая Бесовка (Ташто Бесовка), Александровка (Лёксяндровка), Новая Бесовка (Од Бесовка), Старая Малыкла (Ташто Малыкла), Старая Куликовка (Ташто Куликовка), Новая Куликовка (Од Куликовка), Станция Якушка.

2002-це иень ломанень сёрмадстомань-ловомань коряс Ульяновской областьсэ эрясть 50229 эрзя ломанть, 2010-це иень - 38977 эрзят. Новомалыклинской районсо 2002-це иестэ эрясть 3840 эрзя (22,4\%); 2010-це иестэ - 2893 эрзят $(18,8 \%)$.

Ульяновской областень Новомалыклинской райононь эрзянь велень кортавкстнэ явовить лия эрзянь кортавкстнэнь ды литературань келенть эйстэ кода фонетикань, лексикань истя морфологиянь ёндояк.

Статьянь сёрмадыцятне кортавксонь келень материалонть пурнызь 2019-це иестэ, зярдо ютавтозель экспедиция Равонь томбале эриця эрзятнень эрямо таркаваст. Келень материалонь пурнамсто нежекс ульнесть икеле анокстазь программатне [Агафонова, Рябов 2014; Агафонова Рябов, Рябова 2018]. 
2. Эрзянь кельсэ существительноентень или субстантивированной валонтень сюлмавить-педявтовить суффикст, конатне тевс нолдавить грамматика ёндо азорксчинь невтемга. Сынст вельде невтеви вейке или ламо предметэнь или лицянь лия предметтнэнень или лицятненень кандовомаст: pata-m (старшая сестра-POSS.1SG) 'моя старшая сестра', pata-n (старшая сестра-POSS.1PL) 'мои старшие сестры', kudo-zo (дом-POSS.3SG) 'его дом', kudo-n-zo (дом-PLPOSS.3SG) 'его дома'.

Финнэнь-угрань кельтнесэ азорксчинь суффикстнэнь ванномантень мель явсь учёнойтнень эйстэ васенцекс Матиас Александр Кастрен [1862]. Кастренэнь арсеманзо коряс, финно-угрань, самодиень, тюркань ды лия алтаень кельтнесэ личной аффикстнэ теевсть малав весе местоимениятнестэ [Castren 1862 : 213]. Седе мейле посессивной суффикстнэнь историяст ванномантень мель явсть Й. Буденц [1869 : 40], Х. Паасонен [1903 : 120-123], Й. Синнеи [1910 : 113-120]. Покш путовксозо азорксчинь суффикстнэнь тонавтнемасо Юлиус Марконь, конась седе ламо мель явсь прибалтийско-финской келень азорксчинь суффиксэнь системантень ды сехте пек финнэнь келень системантень [Mark 1925 : 16]. В. А. Суханова азорксчинь суффикстнэнь лемди кода «валонь полавтыця суффикст», секс мекс кой-кона финно-угрань кельтнесэ азорксчинь суффикс марто валонь формасонть невтеви аволь ансяк азоронть лицязо ды числазо, истя жо азоронь предметэнть числазояк [Суханова 1954 : 112-120].

Эрзянь ды мокшонь кельсэ азорксчинь категориянь ванномантень алтызь эсест важодемаст истямо ученойтне, кода М. Е. Евсевьев [1963], Д. В. Бубрих [1947; 1953], Б. А. Серебренников [1967], А. П. Феоктистов [1963], Д. В. Цыганкин [1978], Г. И. Ермушкин [1984], Л. А. Кудашова [2001].

Эрзянь ды мокшонь кельтнесэ покш мель явсь азорксчинь категориянтень А. П. Феоктистов эсензэ монографиясонзо «Категория притяжательности в мордовских языках» [1963]. Тесэ сон домкасто ванны азорксчинь категориянть невтеманзо кода морфология ёндо, истя синтаксис ёндояк.

Эрзянь ды мокшонь кортавкстнэсэ азорксчинь суффикстнэнень явови мель «Очерки мордовских диалектов» книгатнесэ [1961 - 1968]. Башка эряви тешкстамс Д. В. Цыганкинэнь «Грамматические категории имени существительного в диалектах эрзя-мордовского языка (определенностинеопределенности и притяжательности» книганзо [1978]. Те важодемасонть ванновить Мордовиянь эрзянь велень кортавкстнэсэ азорскчинь суффикстнэнь башка ёнксост.

3. Эрзянь грамматикасонть азорксчинь суффиксэнь системась кеместэ сюлмави финнэнь-угрань кельюронть системанть марто. Тешкстасынек, неень шкань эрзянь кельсэ кезэрень азорксчинь суффиксэнь системась пек полавтовсь. Эрзянь литературной кельсэнть ды ламо кортавкстнэсэ човорявсть кой-кона суффикстнэсэ вейке ды ламо обладательтнень ды обладаемойтнень морфология ёндо невтемапелест. Теке марто, улить эрзянь кортавкст, косо неень шкас ванстовсть кезэрень азорксчинь суффикстнэ. Истямотненень эряви кандомс Ульяновской областень Новомалыклинской райононь эрзянь велень кортавкстнэньгак, косо апак полавто кадовсть обладательтнень ды обладаемойтнень ютксо ламочинь явовоматне. Те парсте неяви ало максозь таблицастонть (табл. 1). 
Таблица 1

\begin{tabular}{|c|c|c|c|c|c|}
\hline \multicolumn{6}{|c|}{ I серия «Вейке обладатель ды вейке обладаемой» } \\
\hline Ряд & \multicolumn{2}{|c|}{ к. ф. } & \multicolumn{2}{|r|}{ э. л. } & \multirow[b]{2}{*}{\begin{tabular}{l}
\multicolumn{1}{c}{ рус. } \\
мой дом \\
мой огород \\
мой ребенок \\
моя веревка
\end{tabular}} \\
\hline Монь & $-m$ & $\begin{array}{l}\text { kudo-m } \\
\text { ṕire-m } \\
\text { ejkak-š-um / } \\
\text { ejkakš-4-m } \\
\text { ṕiks-ę-m }\end{array}$ & $-\mathrm{M}$ & $\begin{array}{l}\text { кудо-м } \\
\text { пире-м } \\
\text { эйкакш-о-м } \\
\text { пикс-э-м }\end{array}$ & \\
\hline Тонь & $-t /-t^{\prime}$ & $\begin{array}{l}\text { kudo-t } \\
\text { ṕire }-\dot{t} \\
\text { ejkakš-u-t I } \\
\text { ejkakš-ê- } t \\
\text { ṕiks-ę-t }\end{array}$ & $-\mathrm{T} /-\mathrm{Tb}$ & $\begin{array}{l}\text { кудо-т } \\
\text { пире-ть } \\
\text { эйкакш-о-т } \\
\text { пикс-э-ть }\end{array}$ & $\begin{array}{l}\text { твой дом } \\
\text { твой огород } \\
\text { твой ребенок } \\
\text { твоя веревка }\end{array}$ \\
\hline Сонзэ & $-s o /-s e ̨ /-z o /-z e ̨$ & $\begin{array}{l}\text { kudo-zo } \\
\text { ṕire-ze } \\
\text { ęjkakš-so / } \\
\text { ejkakš-sę } \\
\text { ṕiks-se }\end{array}$ & $-30 / 39$ & $\begin{array}{l}\text { кудо-зо } \\
\text { пире-зэ } \\
\text { эйкакш-о-зо } \\
\text { пикс-э-зэ } \\
\end{array}$ & $\begin{array}{l}\text { его дом } \\
\text { его огород } \\
\text { его ребенок } \\
\text { его веревка }\end{array}$ \\
\hline \multicolumn{6}{|c|}{ II серия «Вейке обладатель ды ламо обладаемойть» } \\
\hline Монь & $-n /-n$ & $\begin{array}{l}\text { kudo-n } \\
\text { ṕíre-ń } \\
\text { ejkakš-u-n } \\
\text { ṕiks-ę- } \\
n \\
\text { ń }\end{array}$ & $\begin{array}{l}-\mathrm{H} /- \\
\mathrm{Hb}\end{array}$ & $\begin{array}{l}\text { кудо-н } \\
\text { пире-нь } \\
\text { эйкакш-о-н } \\
\text { пикс-э-нь }\end{array}$ & $\begin{array}{l}\text { мои дома } \\
\text { мои огороды } \\
\text { мои дети } \\
\text { мои веревки }\end{array}$ \\
\hline $\begin{array}{ll} & \text { ToH } \\
\text { b } & \end{array}$ & -nt/- ńt & $\begin{array}{l}\text { kudo-nt } \\
\text { ṕire-ńt } \\
\text { ejkakš-u-nt } \\
\text { ṕiks-ę-ńt }\end{array}$ & $\begin{array}{l}-\mathrm{T} /- \\
\mathrm{Tb}\end{array}$ & $\begin{array}{l}\text { кудо-т } \\
\text { пире-ть } \\
\text { эйкакш-о-т } \\
\text { пикс-э-ть }\end{array}$ & $\begin{array}{l}\text { твои дома } \\
\text { твои огороды } \\
\text { твои дети } \\
\text { твои веревки }\end{array}$ \\
\hline${ }_{3 \ni} \mathrm{CoH}$ & $-n z o /-n z e$ & $\begin{array}{l}\text { kudo- } \\
\text { nzo } \\
\text { ṕire-nzę } \\
\text { ejkakš-u- } \\
\text { nzo } \\
\text { ṕiks-e-nzes }\end{array}$ & $\begin{array}{l}-\mathrm{H} 3 \mathrm{O} /- \\
\text { Н3э }\end{array}$ & $\begin{array}{l}\text { кудо-нзо } \\
\text { пире-нзэ } \\
\text { эйкакш-о- } \\
\text { нзо } \\
\text { пикс-э-нзэ }\end{array}$ & $\begin{array}{l}\text { его дом } \\
\text { его огород } \\
\text { его ребенок } \\
\text { его веревка }\end{array}$ \\
\hline \multicolumn{6}{|c|}{ III серия «Ламо обладательть ды вейке обладаемой» } \\
\hline Минек & -mok/-mek & $\begin{array}{l}\text { kudo-mok } \\
\text { ṕire-ḿek } \\
\text { ejkakš-mok / } \\
\text { ejkakš-ḿek } \\
\text { ṕiks-ḿek }\end{array}$ & $\begin{array}{l}\text {-нок/- } \\
\text { нек }\end{array}$ & $\begin{array}{l}\text { кудо-нок } \\
\text { пире-нек } \\
\text { эйкакш-о- } \\
\text { нок } \\
\text { пикс-э-нек }\end{array}$ & $\begin{array}{l}\text { наш дом } \\
\text { наш огород } \\
\text { наш ребенок } \\
\text { наша веревка }\end{array}$ \\
\hline Тынк & $-n k$ & $\begin{array}{l}\text { kudo-nk } \\
\text { piŕre-nk }\end{array}$ & -HК & $\begin{array}{l}\text { кудо-нк } \\
\text { пире-нк }\end{array}$ & $\begin{array}{l}\text { ваш дом } \\
\text { ваш огород }\end{array}$ \\
\hline
\end{tabular}




\begin{tabular}{|l|l|l|l|l|l|}
\hline & & $\begin{array}{l}\text { ejkakš-u-nk } \\
\text { ṕiks-ę-nk }\end{array}$ & & $\begin{array}{l}\text { эйкакш-о- } \\
\text { нк } \\
\text { пикс-э-нк }\end{array}$ & $\begin{array}{l}\text { ваш ребенок } \\
\text { ваша веревка }\end{array}$ \\
\hline Сынст & $-s k(-s t)$ & $\begin{array}{l}\text { kudo-sk / } \\
\text { kudo-st } \\
\text { ṕíre-sk / } \\
\text { ṕire-st } \\
\text { ejkakšs-u-sk / } \\
\text { ejkakš-u-st } \\
\text { ṕiks-e-sk / } \\
\text { piks-e-st }\end{array}$ & & $\begin{array}{l}\text { кудо-ст } \\
\text { пире-ст } \\
\text { эйкакш-о-ст } \\
\text { пикс-э-ст }\end{array}$ & $\begin{array}{l}\text { их дом } \\
\text { их огород } \\
\text { ихебенок } \\
\text { их веревка }\end{array}$ \\
& & & & \\
\hline
\end{tabular}

IV серия «Ламо обладательть ды ламо обладаемойть»

\begin{tabular}{|c|c|c|c|c|c|}
\hline Минек & -nok/-ńek & $\begin{array}{l}\text { kudo-nok } \\
\text { ṕire-ńek } \\
\text { ejkakš-u-nok } \\
\text { ṕiks-ę- } \\
\text { ńek }\end{array}$ & $\begin{array}{l}\text {-нок/- } \\
\text { нек }\end{array}$ & $\begin{array}{l}\text { кудо-нок } \\
\text { пире-нек } \\
\text { эйкакш-о- } \\
\text { нок } \\
\text { пикс-э-нек }\end{array}$ & $\begin{array}{l}\text { наши дома } \\
\text { наши } \\
\text { огороды } \\
\text { наши дети } \\
\text { наши } \\
\text { веревки }\end{array}$ \\
\hline Тынк & $-n k$ & $\begin{array}{l}\text { kudo-nk } \\
\text { ṕire-nk } \\
\text { ejkakš-u-nk } \\
\text { ṕiks-ę- } \\
n k\end{array}$ & -НК & $\begin{array}{l}\text { кудо-нк } \\
\text { пире-нк } \\
\text { эйкакш-о- } \\
\text { нк } \\
\text { пикс-э-нк }\end{array}$ & $\begin{array}{l}\text { ваши дома } \\
\text { ваши } \\
\text { огороды } \\
\text { ваши дети } \\
\text { ваши веревки }\end{array}$ \\
\hline Сынст & $-s t(-s k)$ & $\begin{array}{l}\text { kudo-st / } \\
\text { kudo-sk } \\
\text { ṕire-st } \\
\text { ṕire-sk } \\
\text { ejkakš-u-st / } \\
\text { ejkakš-u-sk } \\
\text { ṕiks-ę-st / } \\
\text { ṕiks-e-sk }\end{array}$ & $-\mathrm{cT}$ & $\begin{array}{l}\text { кудо-ст } \\
\text { пире-ст } \\
\text { эйкакш-о-ст } \\
\text { пикс-э-ст }\end{array}$ & $\begin{array}{l}\text { их дома } \\
\text { их огороды } \\
\text { их дети } \\
\text { их веревки }\end{array}$ \\
\hline
\end{tabular}

3.1 Аравтындерясынек карадо-каршо эрзянь литературной келень ды Ульяновской областень Новомалыклинской райононь эрзянь велень кортавксонь азорксчинь суффиксэнь систематнень, несынек, ваннозь кортавкстнэсэ сон карми улеме седе пешксе.

Неть кортавкстнэсэ I ды II сериянь «монь» куронь азорксчинь суффикстнэ кармить улеме вейкеть эрзянь литературной келень суффикстнэнь марто.

I серия:

(1) ńe staka-t ška-t́-ńe-d́e teta-m d ava-m эти тяжелый-PL время-PL-DEF.PL-ABL отец-POSS.1SG и мать-POSS.1SG a v́eč́-i-t jovle-ḿe (ст.бск.) не-NEG любить-PRES.3-PL рассказывать-INF 
'Об этих тяжелых временах мой отец и моя мать не любят рассказывать'

$\begin{array}{lll}\text { (2) } \quad \text { ava-m } & \text { sval } & \text { uĺn-e-ś } \\ \text { мать-POSS.1SG } & \text { всегда-ADV } & \text { быть-INT-1PRET.3SG }\end{array}$

žalića-m-o-k (в.клк.)

жалеющий-PTCP-POSS1.SG-INT-PL

'Моя мама всегда была нашим жалеющей'

II серия:

(3) vačodo karma-ś-t́ kulśs-me apošḱe-t

голодно.ADV стать-1PRET.3SG-PL умирать-INF маленький-PL

brat-u-n $\quad d \mathrm{P}$ sazorka-n (в.клк.)

брат-INT-POSS.1PL и сестра-POSS.1PL.

'С голоду стали умирать мои маленькие братья и сестры'

(4) son ḱekš-i-ń-źe moń ḱeŕ-e-ń (ст.кл.)

он прятать-1PRET-PL-3OBJ.3SG.SBJ.O я-GEN сапог-INT- POSS.1PL.

'Он спрятал мои сапоги'

Кода несынек, эрзянь литературной келень II сериянь 2-це лицясонть «тонь» куросонть ламо обладаемоень невтемга башка суффикс арась. Сонзэ таркас ёвтави I сериянь 2-це лицянь вейкень числань невтиця суффиксэсь -t/-t: kudo-t (вейке, ламо), v́éle-t́ (вейке, ламо). Лиякс меремс, эрзянь литературной кельсэ неть форматне кармить улеме омонимичнойть.

Ваннозь кортавкстнэсэ I ды II сериятне «тонь» куросонть явовить. II сериясонть ванстовсь кезэрень азорксчинь суффиксэсь -nt/-ńt:

I серия:

(5) v́ejḱe tejtér-e-t tonavl-i Uljanovskoj-sę (алкс.) один дочь-INT-POSS.2SG учиться-1PRET.3SG.S Ульяновск-INE

'У тебя одна дочь учится в Ульяновске'

(6) tońt v́ejké ękakš-o-t Malpkla-so (алкс.)

ты.GEN один ребенок-INT-POSS.2SG Малыкла-INE

'У тебя один ребенок в Малыкле'

(7) tońt paro-ĺ skal-o-t (алкс.)

ты.GEN хороший-2PRET.3SG корова-INT-POSS.2SG

'У тебя была хорошая корова'

II серия:

(8) kavto tejtér-i-ń-t tonaví-i-t́ Méleḱes-nę (ст.бск.) два дочь-INT-PL-POSS.2SG учиться-PRES.3-Pl Мелекес-INE

'У тебя две дочери учатся в Мелекесе' 
(9) kolmoękakš-u-n-t tonaví-i-t škola-so(ст.бск.) три ребенок-INT-PL-POSS.2SG учиться-PRES.3-Pl школа-INE 'У тебя трое детей учатся в школе'

(10) kavto skal-u-n-t b́raństę jaḱ-i-t́ stada-v (ст.бск.) два корова-INT-PL-POSS.2SG плохо-ADV ходить-PRES.3-P1 стадо-LAT 'У тебя две коровы плохо ходят в стадо'

Вере максозь невтевкстнэстэ неяви, II сериянь «тонь» куронь -nt/-ńt суффикссэнть ванстовсь кезэрень *-n- пельксэсь, кона невти обладаемойтнень ламочист лангс. Истямо жо азорксчинь суффикс вастови-редяви большеигнатовской диалектсэ ды Нижегородской областень кой-кона северо-западной эрзянь кортавкстнэсэ [Давыдов 1963 : 151-152; Надькин 1968 : 57-60, Ермушкин 1984 : 117-120].

Ваннозь кортавкстнэсэ I ды II сериянь «сонзэ» куросонть -zo/-zęи -nzo/nzę суффикстнэ, кода эрзянь литературной кельсэнтькак, явовить эсь ютковаст ламо обладаемоень невтиця -n- пельксэнть вельде.

I серия:

$\begin{array}{lcc}\text { (11) sonzę } & \text { vejké } & \text { kudo-zo (ст. млк.) } \\ \text { он.GEN } & \text { один } & \text { дом-POSS.3SG } \\ \text { 'У него один дом' } & & \end{array}$

(12) sonzę vejḱe tejtér-zę eŕ-i Śnǵilej-sę (в.клк.) он.GEN один дочь-POSS.3SG жить-PRES.3SG Сенгилей-INE

'Его одна дочь живет в Сенгилее'

(13) vejḱé pata-zo lobut-P leshos-nę (в.клк.)

один сестра-POSS.3SG работать-PRES.3SG лесхоз-

INE

'Одна его старшая сестра работает в лесхозе'

II серия:

(14) sonze kavto kudo-n-zo (ст. млк.)

он.GEN два дом-PL-POSS.3SG

'У него два дома'

(15) sonzę veśse tejtér-i-n-zę kad-P-ź

он.GEN все дочь-INT-PL-POSS.3SG оставить-1PRET-

3PL.SBJ.3SG.OBJ.O

v́ele-ś-́́t (н.млк.)

село-DEF.SG.ACC-DEF.SG

'Все его дочери оставили это село' 
(16) nile pata-n-zo

четыре старшая сестра-PL-POSS.3SG

3PL.SBJ.3SG.OBJ.O

škola-ź-e-ń médaĺ maro (в.клк.)

школа-DEF.SG-INT-ACC медаль с-POST.

'Его четыре старшие сестры закончили школу с медалью'

Ваннозь кортавкстнэсэ башка ёнксокс I сериянь «сонзэ» куронь валонь форматнесэ карми улеме -so/-sę азорксчинь суффиксэнть саевемазо. Те суффиксэсь тевс нолдави сестэ, зярдо сон поладови гайттеме согласной лангс прядовиця валлувонтень. Эрзянь литературной кельсэнть ды ламо эрзянь кортавкстнэсэ истямо валлувонтень поладови -zo/-zе̨суффиксэсь. Те парсте неяви-редяви ало максозь таблицастонть (табл. 2).

Таблица 2

\begin{tabular}{|c|c|c|}
\hline к. ф. & Э. Л. & pyc. \\
\hline$\check{c} a k \check{s} s-s o$ & чакш-о-зо & его кувшин \\
\hline ḿekš-se & мекш-е-зэ & его пчела \\
\hline ṕiks-sę & пикс-э-зэ & его веревка \\
\hline ejkakš-so & эйкакш-о-3о & его ребенок \\
\hline levks-sę & левкс-э-зэ & его детеныш \\
\hline ṕenč-sę & пенч-е-зэ & его ложка \\
\hline brat-so & брат-о-зо & его брат \\
\hline
\end{tabular}

Минек койсэ, кортавксонь -so/-se азорксчинь суффиксэсь карми улеме кезэрень суффиксэкс, кона ванстовсь уралонь кельюронь азорксчинь суффиксэнь системастонть «сонзэ» куронь вейке предметэнь невтемга.

Тешкстасынек, эрзянь литературной кельсэнть согласной лангс прядовиця валтнэсэ азорскчинь суффиксэсь поладови интерфикс вельде. Ваннозь кортавкстнэсэ азорксчинь суффиксэсь поладови видьстэ согласной валлувонтень. Теке жо явлениясь вастневи-редяви северо-западной диалектэнь кой-кона кортавкстнэсэ [Давыдов 1963: 160 - 161].

3.2 Содазь, эрзянь литературной кельсэ III сериясонть ламо обладателень ды вейке обладаемоень невтемга башка азорксчинь суффикст арасть. Сынь кармить улеме вейкеть IV сериянь азорксчинь суффикстнэнь марто, лиякс меремс, III ды IV сериянь азорксчинь суффикстнэ кармить улеме омонимичнойть, ды те омонимиясь явови эрзянь литературной кельсэ ды истямо кортавкстнэсэ ансяк контекстсэ: кудо-нок «наш дом» и кудо-нок «наши дома», пире-нек «наш огород» и пире-нек «наши огороды».

Ульяновской областень Новомалыклинской райононь эрзянь велень кортавкстнэсэ парсте ванстовсь III сериясонть «минек» куросонть васенце лицянь кезэрень *-mok/*-mek суффиксэсь. Те азорксчинь суффикссэнть -mпельксэсь невти васенце лицянть ды вейке обладаемоенть лангс, -k пельксэсь невти ламо обладатель лангс.

(17) tora-m-o-k ęŕ-i goro-co Śenǵilej-sę (н.бск.) 
сын-POSS.1SG-INT-PL жить-PRES.3SG.S город-INE Сенгилей-INE

'Наш сын живет в городе Сенгилей'

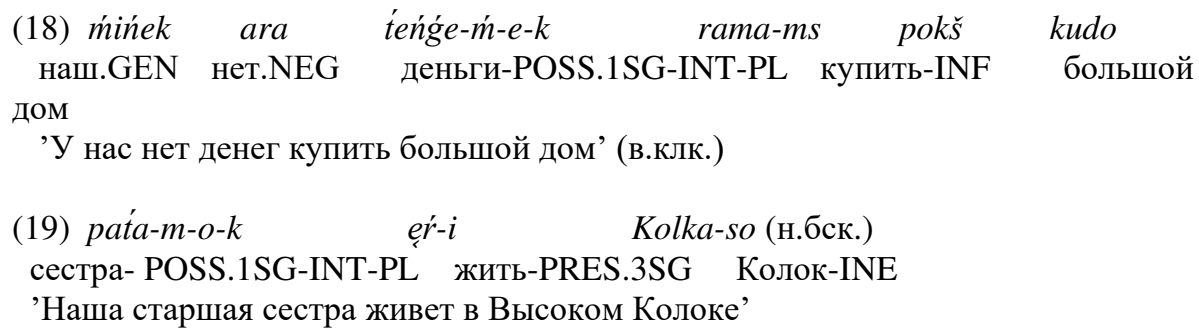

Теке жо суффиксэсь келейстэ вастневи северо-западной диалектсэнть Атяшевской, Ардатовской райононь кой-кона кортавкстнэсэ, Чувашиянь, Нижегородской ды Самарской областень Шенталинской райононь кортавкстнэсэ [Давыдов 1963 : 151-154; Ермушкин 1967 : 109; Цыганкин 1978 : 42-46].

Ваннозь кортавкстнэсэ «минек» куронь III сериянь -mok/-ḿek суффиксэсь карадо-каршо аравтови «минек» куронь IV сериянь -nok/-ńek суффиксэнтень. Те парсте неяви ало максозь невтевкстнэстэ.

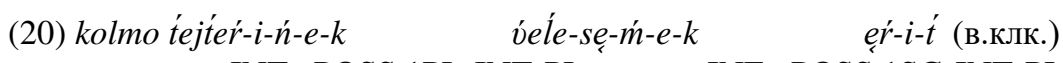
три дочь-INT- POSS.1PL-INT-PL село-INE- POSS.1SG-INT-PL житьPRES.3-PL

'Наши три дочери живут в нашем селе'

(21) MalPkla-so kavto škola-n-o-k (ст.бск.)

Малыкла-INE два школа-POSS.1 PL-INT-PL

'В Малыкле у нас две школы'

(22) ńev učitél-i-ń-e-k karḿ-i-t́t pand-mo sv́et-P-ń теперь учитель-INT-POSS.1PL-INT-PL быть-FUT.3-PL платить-INF светINT-GEN

kis-ḱ (в.клк.)

3a-POST- ENCL

'Теперь наши учителя будут платить и за свет'

Ваннозь кортавкстнэсэ III сериянь «тынк» куросонть ламо обладателень ды вейке обладаемоень невтемга, кода эрзянь литературной кельсэнтькак, башка суффикс арась. Сонзэ таркас тевс нолдави IV сериянь «тонь» куронь суффиксэсь -nk,саемга:
(23) $t$ Pnk pokśta-n-k
eŕ-i véle-sę (ст.кл.)
вы.GEN дедушка-PL-POSS.2.PL жить-PRES.1SG село-INE
'Ваш дедушка живет в селе' 


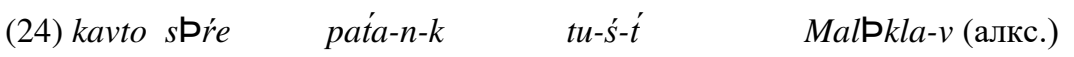
два старший тетя-PL-POSS.2.PL уехать-1PRET.3-PL Малыкла-LAT 'Две ваши тети уехали в Малыклу'

(25) mon soda-s-a tPnk pokš pat́a-n-k (ст.бск.)

я знать-3SG.OBJ.-PRES.1SG.SBJ.O вы-GEN старший сестра-PLPOSS.2.PL

' Я знаю вашу старшую сестру'

Эрзянь литературной кельсэнть ды ламо кортавкстнэсэ III ды IV сериятнень «сынст» куросо тевс нолдави -st азорксчинь суффиксэсь: пакся-ст «их поле» и пакся-cm «их поля», вир-е-сm «их лес» и вир-е-сm «их леса».

Ульяновской областень Новомалыклинской райононь эрзянь велень кортавкстнэсэ III ды IV сериянь «сынст» куронь азорксчинь невтемга тевс нолдавить кавто суффикст: -st ды -sk. Ламо обладателень ды вейке обладаемоень невтемга седе сеедьстэ саеви -st суффиксэсь, сестэ кода ламо обладателень ды ламо обладаемоень невтемга тевс нолдави -skcyффиксэсь, саемга:

III серия

(26) $s \mathrm{P}_{n s t} \quad$ uinéśs v́ejké staka sumka-s-k (в.клк.) они.GEN быть-1PRET.3SG один тяжелый сумка-POSS.3SG-PL

'У них была одна тяжелая сумка'

(25) $s \mathrm{P}_{n s t} \quad \dot{m} e \dot{l}-e-s-t \quad m o l-s ́$

они.GEN желание-INT-POSS.3SG-PL идти-1PRET.3SG

téta-s- $k \quad u c ̌ e-z ́$ (алкс.)

отец- POSS.3 SG-PL ждать-GRD

'Они соскучились ожидая отца'

(26) $s \mathrm{P}_{n s t} \quad$ vejḱe pata-s-k (в.клк.)

они.GEN один сестра-POSS.3 SG-PL

'У них одна старшая сестра'

IV серия

(27) $s \mathrm{P} n s t \quad$ lamo teńǵe-s-t (алкс.)

они.GEN много деньги-POSS.3SG-PL

'У них много денег'

(28) $s \mathrm{P}_{n s k}$ ṕeḱe-s-t vač- $(s)-\dot{t}$ (ст. млк.)

они.GEN живот- POSS.3SG-PL голодать-(1PRET.3)-PL

'Они проголодались' 
(29) $s \mathrm{P}_{n s t} \quad$ lamo léla-s-t (н.бск.)

они.GEN много брат-POSS.3SG-PL

'У них много старших братьев'

Неень шкасто стака явомс, зярдо тевс нолдави -st суффиксэсь, а зярдо -sk суффиксэсь, сеедьстэ сынст ёвтыть эрицятне човорязь.

4. Меельцекс эряви ёвстамс, Ульяновской областень Новомалыклинской райононь эрзянь велень кортавкстнэсэ азорксчинь суффиксэнь системасонть неень шкас кадовсть апак полавто кезэрень ёнкст:

1. Неть кортавсктнэсэ II сериянь «тонь» куросо ванстовсь кезэрень *-nпельксэсь, кона невти обладаемойтнень ламочист лангс. Тень лангс ванозь, «тонь» куронь I ды II сериянь валонь форматне явовить эсь ютковаст: -t/-t (I серия) ды -nt/-ńt(II серия). Эряви тешкстамс, эрзянь литертурной кельсэнть ды лия ламо кортавкстнэсэ истямо явовома арась. Саемга: kudo-t (дом-POSS.2SG) 'твой дом' - kudo-n-t (дом-PL-POSS.2SG) 'твои дома', ṕire-t́( огород-POSS.2SG) 'твой огород' - ṕire-ń-t́(огород-PL-POSS.2SG) 'твои огороды', ejkakš-o-t (ребенок-INT-POSS.2SG) 'твой ребенок' - ejkakš-o-n-t (ребенок-INT-PLPOSS.2SG) 'твои дети', ṕiks-ę-t́(веревка-INT-POSS.2SG) 'твоя веревка' - ṕiks-ę$n$ - $t$ (веревка-INT-PL-POSS.2SG) 'твои веревки'.

2. I сериянь «сонзэ» куронь согласной лангс прядовиця валонь форматнесэ вастови-редяви уралонь кельюронь *-so/*-sе̨азорксчинь суффиксэсь. Эрзянь литературной кельсэнть ды ламо эрзянь кортавкстнэсэ истямо валлувонтень поладови ансяк -zo/-zе̨суффиксэсь. Саемга: ṕiks-s4 (веревка-POSS.3SG) 'его веревка', ejkakšso (ребенок-POSS.3SG) 'его ребенок', с̌aǩs-so (горшокPOSS.3SG) 'его горшок', brat-so (брат-POSS.3SG) 'его брат'.

3. III сериянь «минек» куросо ванстовсь васенце лицянь кезэрень *-mok/*ḿek суффиксэсь, кона карадо-каршо аравтови IV сериянь *-nok/*-ńek суффиксэнть марто. Саемга: tora-m-o-k (сын-POSS1SG-INT-PL) - tora- $n-o-k$ (сын-POSS1PL-INT-PL); v́ele-ḿ-e- $k$ (село-POSS1SG-INT-PL) - v́ele-ń-e- $k$ (селоPOSS1PL-INT-PL).

4. III сериянь «сынст» куронь ламо обладателень ды вейке обладаемоень невтемга саеви -st суффиксэсь, IV сериясо азорксчинь невтемга тевс нолдави -sk суффиксэсь. 


\section{Киртявкст}

к. ф. - кортавксонь формат, э. л. - эрзянь литературной келень формат, рус. - рузонь.

Глоссатне: $\mathbf{1}$ - васенце лиця, $\mathbf{2}$ - омбоце лиця, $\mathbf{3}$ - колмоце лиця, $\mathbf{A B L}$ аблатив, ACC - аккузатив, ADV - наречия, DEF - невтемачинь полавтнема, ENCL - частица, FUT - сыця шка, GEN - генитив, GRD - деепричастия, INE инессив, INF - инфинитив, INT - интерфикс, LAT - латив, NEG - отрицания, NOM - номинатив, O - объект марто полавтнема, OBJ - объект, PL -ламонь числа, POSS - азорксчи, POST - валмельгакс, PRES - неень шка, PRET претерит, PTCP - причастия, SG - вейкень числа, SBJ - субъект, $\mathbf{S}$ - субъект марто полавтнема.

алкс. - Ульяновской областень Новомалыклинской райононь Александровка велень кортавкс, в.клк. - Ульяновской областень Новомалыклинской райононь Высокий Колок велень кортавкс, н.бск. - Ульяновской областень Новомалыклинской райононь Новая Бесовка велень кортавкс, н.млк. Ульяновской областень Новомалыклинской райононь Новая Малыкла велень кортавкс, ст.бск. - Ульяновской областень Новомалыклинской райононь Старая Бесовка велень кортавкс, ст.кл. - Ульяновской областень Новомалыклинской райононь Старая Куликовка велень кортавкс, ст. млк. - Ульяновской областень Новомалыклинской райононь Старая Малыкла велень кортавкс.

\section{Acknowledgements}

Исследование выполнено при финансовой поддержке РФФИ в рамках научного проекта № 19-012-00323.

\section{Тевс нолдазь лисьмапрят}

1. Агафонова Н. А., Рябов И. Н., 2014 Диалектологический атлас эрзянского языка. Программа-вопросник (Морфология), Саранск.

2. Агафонова Н. А., Рябов И. Н., Рябова Г. В., 2018 Программа по сбору диалектного материала эрзянского языка, Саранск.

3. Бубрих Д. В. 1947, Эрзя-мордовская грамматика - минимум. Саранск.

4. Бубрих Д. В. 1953, Историческая грамматика эрзянского языка. Саранск.

5. Давыдов М. М. 1963, Больше-Игнатовский диалект эрзя-мордовского языка. Очерки мордовских диалектов, Т. 2, Саранск, 118 - 233.

6. Евсевьев М. Е.1963, Основы мордовской грамматики. - Избранные труды, Т. 4, Саранск.

7. Ермушкин Г. И. 1967, Имя существительное и глагол в северо-западных говорах эрзя-мордовского языка. - Вопросы мордовского языкознания. Вып. XXXII, Саранск, $104-143$.

8. Ермушкин Г. И. 1984, Ареальные исследования по восточным финно-угорским языкам (эрзя-мордовский язык), Москва. 
9. Кудашова Л. А., 2001 Посессивность в эрзянском и венгерском языках. Автореферат диссертации на соискание ученой степени кандидата филологических наук, Саранск.

10. Надькин Д. Т. 1968, Морфология нижнепьянского диалекта эрзя-мордовского языка. - Очерки мордовских диалектов, Т. 5, Саранск, 3 - 198.

11. Очерки мордовских диалектов: Т. 1, 1961. - 396 с.; Т. 2, 1963a. - 448 с.; Т. 3, 1963б. - 276 с.; Т. 4, 1966. - 382 с.; Т. 5, 1968. - 399 с.Саранск: Мордовскоекнижное издательство.

12. Серебренников Б. А. 1967, Историческая морфология мордовских языков. Москва.

13. Суханова В. С., 1954 О притяжательных формах в финно-угорских языках. - Ученые записки Карело-финского государственного университета, Т. 4, вып.1, Петрозаводск.

14. Феоктистов А. П. 1963, Категория притяжательности в мордовских языках. Саранск.

15. Цыганкин Д. В. 1978, Грамматические категории имени существительного в диалектах эрзя-мордовского языка (определенности-неопределенности и притяжательности). Саранск.

16. Budenz J., 1869 Nachweis und Erklärung einer ursprunglicheren Gestalt der pluralisher Possessivaffixe in der ugrischen Sprachen. - Ugrische Sprachstudien, Bd. I.

17. Castren M. A., 1862 Über die Personalaffixe inden altaischen Sprachen. -Nordische Reisen und Forschunger. Kleiner Schriften, Bd V. St.-Petersburg.

18. Mark Julius, 1925 Die Possessivaffixe in der ugrischen Sprachen. - «Memoires de la Sociètė Finno-ougrienne», tomme LIV, Helsinki.

19. Paasonen H., 1903 Mordwinische Lautlehre. Akademische Abhandlung, Helsingfors, 2-e изд-е. MSFOu, XXII.

20. Szinnyei Josef, 1910. Finnisch-ugrische Sprachwissenschaft. Leipzig. 